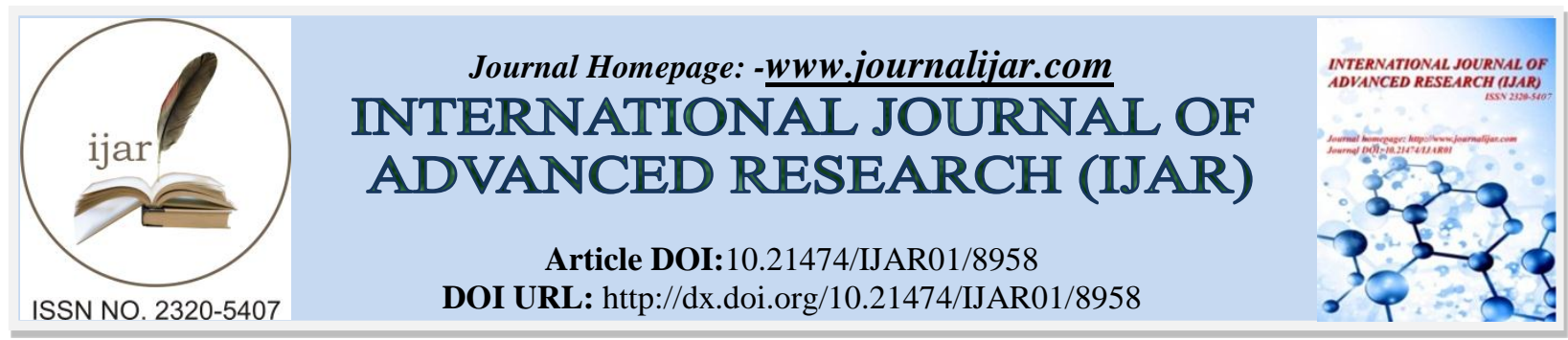

RESEARCH ARTICLE

\title{
THE EFFECT OF DEBT LEVEL, SALES VOLATILITY, AND TEMPORARY DIFFERENCES TO EARNINGS QUALITY.
}

Anita Holly ${ }^{1}$, Andi Kusumawati ${ }^{2}$ And Nirwana ${ }^{2}$.

1. Magister of Accounting, Faculty of Economics and Business, Hasanuddin University, Indonesia.

2. Department of Accounting, Faculty of Economics and Business, Hasanuddin University, Indonesia.

\section{Manuscript Info}

Manuscript History

Received: 22 February 2019

Final Accepted: 24 March 2019

Published: April 2019

Key words:-

debt level, sales volatility, smoothness, ERC.

\section{Abstract}

The research aimed to discuss the determinants factors of earnings quality in Indonesia capital market. Those factors were debt level, sales volatility, and temporary differences. The earnings quality was measured using attributes are smoothness and Earnings Response Coefficient (ERC). The research employed the secondary data in the form of financial statement of company, stock prices of company, and composite stock prices index starting from 2015 until 2017. This research was analysed using multiple regression analysis with IBM SPSS Statistics 21 program.

The result of the testing showed that debt level and sales volatility had a significant effect with earnings quality measured using smoothness' attributes. But, the result of the testing earnings quality measured using ERC attributes, showed that there was no independent variable had significant effect.

Copy Right, IJAR, 2019,. All rights reserved.

\section{Introduction:-}

Earnings is financial statement information that is most widely used by both internal parties and external parties in decision making (Fanani, 2010; Kasiono and Fachrurrozie, 2016). Information on company performance, especially earnings, is needed to assess potential changes in economic resources that may be controlled in the future. Therefore, the earnings quality becomes important. Earnings quality is an indicator of earnings disclosure ability to predict cash flow in the future (Penman, 2001; Warrard, 2017). Low earnings quality means that earnings can not accurately predict future cash flows.

Cases of accounting scandals that afflict national and multinational companies indicate a problem related to the earnings quality. The problem is "is the quality of the year earnings going well?" (Pagalung and Sudibdyo, 2012). The current year's earnings is said to be of quality if earnings can be used as a reliable indicator to predict future earnings (Penman, 2001).

There are several factors that can influence earnings quality, such as debt level, sales volatility, and temporary differences. The company's ability to generate earnings is inseparable from its capital to finance its operations. Debt is an alternative external funding that can be used by companies by binding themselves to contracts with creditors. Debt can indeed increase the company's capital, but consequently, the company must pay principal and interest installments at maturity without considering the company's financial condition.

Corresponding Author:-Anita Holly.

Address:-Magister of Accounting, Faculty of Economics and Business, Hasanuddin University, Indonesia. 
The earnings quality is also affected by sales volatility. Sales volatility is the degree of sales spreading. The many accounting methods that can be used by financial report compilers can positively and negatively affect the company's earnings.

In addition to the debt level and sales volatility, earnings quality is also affected by temporary differences. Temporary differences are the difference between accounting earnings and fiscal earnings because of time differences. Companies do not need to make double bookkeeping to obtain accounting earnings and fiscal earnings, but companies need to carry out fiscal reconciliation only. This can create opportunities for companies to conduct earnings management.

This study included the company size as control variable. Company size is a proxy for price infomatization (Nofianti, 2014). Large companies tend to have stable conditions, so they are considered to have better earnings quality than small ones.

This study used attributes of earnings quality measurement with smoothness that represent the perspective of company financial performance from current year's earnings because operating cash flows show the stability of company earnings generated from economic transactions (Ramadan, 2015) and Earnings Response Coefficient (ERC) which represent the perspective of company performance in the stock market because the ERC measures abnormal returns from the response of unexpected components of the company. The formulation of the problem in this study was whether the level of debt, sales volatility, and temporary differences affect the earnings quality?

\section{Theory Concept Agency Theory}

Agency theory states that the relationship of agency arises when one person or more (principal) employs another person (agent) to provide a service and to delegate authority and decision making to the agent (Jensen and Meckling, 1976). The agent (manager) should act based on stockholder's interest, but in fact, manager and stockholder has different interest (conflict of interest). This conflict is not only happen between stockholder and manager, but also creditor and government. Managers want to maximize his compensation, stockholders want to decrease the tax cost to achieve high return, creditors want the company to fullfill the debt covenants, and the government want to maximize company's tax. The low of debt level, sales volatility, and temporary differences indicate that the management carries out its contract in accordance with the interests of the shareholders. Managers act optimally because they know that shareholders control their behavior through monitoring activities. A supervisory approach by external parties can also be carried out by creditors through the use of debt and the government through tax returns.

\section{Signal Theory}

Signal theory states that information needs to be conveyed by the company to outsiders to reduce the asymmetry of information because the company knows more than outside parties. According to Akerlof (1970), when buyers do not have information regarding product specifications and only have a general perception of the product, the buyer will assess all products at the same price regardless of product quality. This can be overcome if the seller communicates their product by giving a signal in the form of information about the product quality. The low debt levels, low sales volatility, and low temporary differences are positive signals to the earnings quality.

\section{Efficient Market Theory}

According to Fama (1970), in an efficient market, prices will fully reflect available information and as an implication, prices will react immediately without any bias towards new information. The price of securities balance results in no opportunity for investors to obtain abnormal returns from the difference in price of stock securities. The low debt level, sales volatility, and temporary differences will be positively responded by investors because the information can increase certainty regarding to the acquisition of cash flow in the future.

\section{Method:-}

The research design used was quantitative type that described the relationship and influence between independent variables (debt level, sales volatility, and temporary differences) and the dependent variable (earnings quality). This study carried out documentation method to collect the data. Data was collected by collecting company financial statements, company stock prices, and composite stock price index. This study used multiple linear regression analysis with the IBM SPSS Statistic 21 program. The regression equation in this study was as follow.

$\mathrm{KL}_{\mathrm{n}, \mathrm{t}}=\alpha_{0}+\alpha_{1}$ Debt Level $+\alpha_{2}$ Sales Volatility $+\alpha_{3}$ Temporary Differences $+\alpha_{4}$ Company Size $+\varepsilon_{1} \quad \ldots(1)$ 
The population in this study was the whole companies listed on the Indonesia Stock Exchange (IDX) in 2015-2017. This study used purposive sampling with the criteria (1) reporting current and deferred tax expense in the earnings statement in the year of observation, (2) not experiencing negative operating cash flows during the year of observation, (3) not experiencing losses , (4) financial statements in rupiah currency, and (5) complete financial statements and ending on 31 December. The final sample in this study consisted of 108 company samples.

\section{Earnings Quailiy}

Earnings quality is an indicator of the ability of earnings disclosure to predict cash flow in the future. The earnings quality in this study was measured by two attributes, namely smoothness and Earnings Response Coefficient (ERC). Smoothness was measured using proxies in Gaio and Raposo (2011), namely $\operatorname{Smooth}_{\mathrm{i}, \mathrm{t}}=\frac{\sigma \mathrm{NIBE}_{\mathrm{i}, \mathrm{t}}}{\sigma \mathrm{CFO}_{\mathrm{i}, \mathrm{t}}}$. ERC measured by using proxy in Sari and Lyana's study (2015), namely regression coefficients from Unexpeded Earnings and Cummulative Abnormal Return.

\section{Debt Level}

The debt level shows the ratio of debt usage by the company. The debt level in this study was measured by the proxies in some studies, such as Fanani (2010), Marnilin and Darmansyah (2015), Malahayati et al (2015), Kasiono and Fachrurrozie (2016), Susilo and Anggraeni (2016), and Nuraeni and Putri (2018), namely DR Det, $_{i}=\frac{\text { Total Debt }_{i, t}}{\text { Total Asset }_{i, t}}$.

\section{Sales Volatility}

Sales volatility is the standard deviation of sales divided by total assets. Sales volatility in this study was measured by proxy in some studies, such as Dechow and Dichev (2002), Fanani (2010), Pagalung and Sudibdyo (2012), and Kasiono and Fachrurrozie (2016), namely $\mathrm{VS}_{\mathrm{i}, \mathrm{t}}=\frac{\sigma\left(\operatorname{Sales}_{\mathrm{i}, \mathrm{t}}\right)}{\text { Total Asset }_{\mathrm{i}, \mathrm{t}}}$.

\section{Temporary Differences}

Temporary differences occur because of differences in treatment between the Financial Accounting Standards and tax laws and regulations. The difference between accounting earnings and fiscal earnings in this study was measured

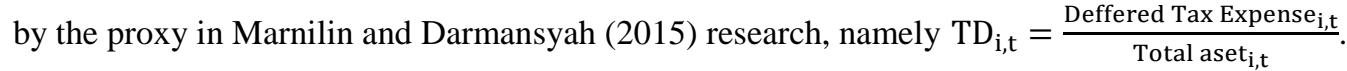

\section{Company Size}

Company size shows the size of the company that can be seen from the assets of the company. The size of the company in this study was measured by the proxy available in the study of Rajizadeh and Rajizadeh (2013), Alfiarini and Muid (2015), Malahayati et al (2015), Dewi and Putri (2015), and Susilo and Anggraeni (2016), Nuraeni et al (2018), namely CS $=$ Ln Total Asset $_{\mathrm{i}, \mathrm{t}}$.

\section{Research Results And Discussion:-}

Judging from the results in testing the data normality in this study, we found that the data is not equally distributed. As the data transformation gave the results, the researchers would affirm that data equally distributed. A good regression analysis must match to the classic assumption test. Based on the results of the classic assumption test, it was found that there were no heteroscedasticity, multicolonierity, and autocorrelation.

The testing of multiple linear regression analysis to test the strength effect and direction of influence between the dependent variable (earnings quality) and independent variables (level of debt, volatility of sales, and temporary differences) were supported by company size. Based on the multiple linear regression analysis, the beta coefficient and error value calculated for each research model are 0,962 and $0,9711\left(\varepsilon \mathrm{I}=\sqrt{1-\mathrm{R}^{2}}=\sqrt{1-0,075}=0,962\right.$ and $\left.\varepsilon \mathrm{I}=\sqrt{1-\mathrm{R}^{2}}=\sqrt{1-0,057}=0,9711\right)$ can be included in the regression equation which can be arranged mathematically as follows:

Ln $\mathrm{EQ}_{1}=0,633-1,410 \mathrm{DR}+0,227 \mathrm{Ln} \mathrm{VS}+39,899 \mathrm{TD}+0,042 \mathrm{CS}+0,962$

$\mathrm{EQ}_{2}=3,425+2,889 \mathrm{DR}-0,355 \mathrm{Ln} \mathrm{VS}+121,942 \mathrm{TD}-0,724 \mathrm{CS}+0,9711$

Table 1:-Multiple Linear Regression Analysis

\begin{tabular}{|l|c|c|}
\hline Variable & $\begin{array}{c}\text { Model 1 } \\
\text { (Natural Logarithm of } \\
\text { Smoothness) }\end{array}$ & $\begin{array}{c}\text { Model 2 } \\
\text { (Earnings Response } \\
\text { Coefficient) }\end{array}$ \\
\hline Debt Ratio (DR) & $-2,273 * *$ & 1,393 \\
& $(-1,410)$ & $(2,889)$ \\
\hline
\end{tabular}




\begin{tabular}{|l|c|c|}
\hline Natural Logarithm of Sales Volatility (VS) & $2,072^{* *}$ & $-0,969$ \\
& $(0,227)$ & $(-0,355)$ \\
\hline Temporary Differences (TD) & 1,074 & 0,982 \\
& $(39,899)$ & $(121,942)$ \\
\hline Company Size (CS) & 0,604 & $-3,118^{*}$ \\
& $(0,042)$ & $(-0,724)$ \\
\hline Adjusted R & 0,075 & 0,057 \\
\hline
\end{tabular}

*Significance level of $1 \%$

** Significance level of $5 \%$

The adjusted coefficient of determination (adjusted R2) in model 1 and model 2 amounted to 0.075 and 0.057 , respectively. This implied that in model 1 , independent variables (debt level, sales volatility, and temporary differences) supported by company size can predict the dependent variable (earnings quality) with natural logarithm of smoothness attributes which can provide information up to $7.5 \%$ needed. In other words, there were $92.5 \%$ (100\% $-7.5 \%$ ) other things that affect the earnings quality. Meanwhile, model 2 in this study, independent variables (debt level, sales volatility, and temporary differences) that were supported by company size can predict the dependent variable (earnings quality) with the Earnings Response Coefficient attribute, provides information $5.7 \%$. In other words, there were $94.3 \%(100 \%-5.7 \%)$ of other things that affect the earnings quality.

The results of the F statistical test showed a significance value of 0.017 and 0.039 for model 1 and model 2 . Significant values $(0.017$ and 0.039$)<(0.05)$. This meant that the regression model built can significantly explain the relationship between the independent variable and the dependent variable. Thus, the models and theories that are built were quite good because they were in accordance with the conceptual framework.

\section{Conclusion:-}

The conclusions in this study are as follows.

1. Debt level had a positive effect on earnings quality with smoothness attributes. This showed that companies with high debt would enable managers to gain the trust of the investors and creditors. Debt level didn't affect earnings quality with the Earnings Response Coefficient (ERC) attribute. This showed that high or low debt owned by the company will not affect market perceptions of earnings quality, because stock price movements in the Indonesian capital market are caused by market psychological factors. Investors had no good concern for how high the company's debt, because they paid more attention to the use of funds that was more effective and efficient by the management of the company.

2. Sales volatility had a negative effect on earnings quality with the smoothness attribute. This is because information about low sales volatility is a positive signal that the company was willing to provide regarding the earnings quality. Low sales volatility also showed the success of management to maximizing the interests of stockholders by increasing the certainty of future cash flows. Sales volatility does not affect the earnings quality with the ERC attribute. The volatility of sales was just normal because of the fluctuating economic conditions. Information about sales volatility had no effect upon market perceptions of the company's earnings quality. The capital market in Indonesia still dominated by market psychological factors.

3. Temporary differences didn't affect earnings quality with smoothness and ERC attributes. Temporary differences can create restoration to the company's earnings. In addition, temporary differences that occur in companies are caused by differences in the rules between Financial Accounting Standards with tax laws and regulations, not from earnings management activities. Management carried out its duties in accordance with applicable regulations. Therefore, information regarding temporary differences wasn't used by the market for investment decision making.

The limitations in this study and suggestions for further research are as follows.

1. This study only used internal company variables, regardless of conditions outside the company that can affect earnings quality. The next research should include the company's external variables, such as economic conditions, risk preferences, and market psychological factors.

2. This study only used company annual reports, which are published no later than March 31. Further research, if possible, should use quarterly reports, which are issued no later than the last day of the following month per each period. 


\section{Refferences:-}

1. Akerlof, G. A. 1970. The Market For "Lemons" Quality Uncertainty and the Market Mechanism. The Quarterly Journal of Economics, 84 (3), 488-500.

2. Alfiarini, A dan Muid, D. 2015. Pengaruh Book Tax Differences terhadap Earnings Persistence dengan Komponen Akrual sebagai Variabel Moderasi pada Perusahaan Jasa di Indonesia. Diponegoro Journal of Accounting, 4 (4), 1-15.

3. Dechow, P. M. Dan Dichev, I. D. 2002. The Quality of accruals and Earnings: The Role of Accrual Estimation Errors. The Accounting Review, 77, 35-59.

4. Dewi, N. P. L. dan Putri, I. G. A. M. A. D. 2015. Pengaruh Book Tax Differences, Arus Kas Operasi, Arus Kas Akrual, dan Ukuran Perusahaan pada Persistensi Laba. E-Jurnal Akuntansi Universitas Udayana, 10 (1), 244260.

5. Fama, E. 1970. Efficient Capital Markets - A Review of Theory and Empirical Work, Journal of Finance, 25 (2), 383-417.

6. Fanani, Z. 2010. Analisis Faktor-faktor Penentu Persistensi Laba. Jurnal Akuntansi dan Keuangan Indonesia, 7 (1), 109-123.

7. Gaio, C dan Raposo, C. 2011. Earnings Quality and Firm Valuation: International Evidence. Accounting and Finance 51, 467-499.

8. Jensen, M. dan Meckling, W. H. 1976. Theory Of The Firm: Managerial Behavior Agency Cost, and Ownership Structure. Journal of Finance Economics 3, 305-360.

9. Kasiono, D. dan Fachrurrozie. 2016. Determinan Persistensi Laba pada Perusahaan Manufaktur yang Terdaftar di BEI. Accounting Analysis Journal, 5 (1), 1-8.

10. Malahayati, R., Arfan, M., dan Basri, H. 2015. Pengaruh Ukuran Perusahaan dan Financial Leverage terhadap Persistensi Laba dan Dampaknya terhadap Kualitas Laba (Studi pada Perusahaan yang Terdaftar di Jakarta Islamic Index). Jurnal Magister Akuntansi Pascasarjana Universitas Syiah Kuala, 4(4), 79-91.

11. Marnilin, F., Mulyadi, JMV., dan Darmansyah. 2015. Analisis Determinan terhadap Persistensi Laba pada Perusahaan Jasa di BEI. Media Riset Akuntansi, Auditing, \& Informasi, 15 (1), 89-102.

12. Nofianti, N. 2014. Pengaruh Struktur Modal, Ukuran Perusahaan, dan Kebijakan Dividen terhadap Koefisien Respon Laba. Jurnal Etikonomi, 13 (2), 118-147.

13. Nuraeni, R, Mulyati, S., dan Putri, T.E. 2018. Faktor-faktor yang Mempengaruhi Persistensi Laba (Studi Kasus pada Perusahaan Property dan Real Estate yang Terdaftar di Bursa Efek Indonesia Tahun 2013-2015). Accruals, $1(1), 82-112$.

14. Nuraeni, R, Mulyati, S., dan Putri, T.E. 2018. Faktor-faktor yang Mempengaruhi Persistensi Laba (Studi Kasus pada Perusahaan Property dan Real Estate yang Terdaftar di Bursa Efek Indonesia Tahun 2013-2015). Accruals, 1 (1), 82-112.

15. Pagalung, G. Dan Sudibdyo, B. 2012. The Determinant Factors of Earnings Quality and Economic Consequences. Ekuitas: Jurnal Ekonomi dan Keuangan, 16 (1), 105-122.

16. Penman, S. H. 2001. On Comparing Cash Flow and Accrual Accounting Models For use In Equity Valuation. Columbia University, 1-21.

17. Rajizadeh, S. dan Rajizadeh, S. 2013. Examining the Factors Affecting Earnings Persistency among the Listed Firms in Tehran Stock Exchange. European Online Journal of Natural and Social Sciences 2 (3), 2073-2079.

18. Ramadan, I. Z. 2015. Earnings Quality Determinants of the Jordanian Manufacturing Listed Companies. Internatioanal Journal of Economics and Finance, 7 (5), 140-146.

19. Sari, D. Dan Lyana, I. D. D. 2015. Book Tax Differences dan Kualitas Laba. Jurnal Akuntansi Multiparadigma, 6(3), 341-511.

20. Susilo, T. P. dan Anggraeni, B. M. 2016. Analisis Pengaruh Volatilitas Arus Kas, Tingkat Utang, Siklus Operasi, dan Ukuran Perusahaan terhadap Persistensi Laba. Media Riset Akuntansi, 6 (1), 4-21 http://jurnal.bakrie.ac.id/index.php/journal_MRA/article/view/1735. Diakses tanggal 6 Desember 2018.

21. Warrard, L. H. 2017. The Influence of Leverage and Profitability on Earnings Quality: Jordanian Case. International Journal of Academic Research in Business and Social Sciences, 7 (10), 62-81. 